\title{
THE TRUTH IN ARISTOTLE AND SOPHONIAS
}

\author{
Alexantra Ntotsika
}

DOI: $10.17846 /$ CL.2017.10.1.36-42

\begin{abstract}
NTOTSIKA, Alexantra. The Truth in Aristotle and Sophonias. The purpose of the article is to discover the philosophical game between truth and falsehood, as it is presented in the Aristotelian treatise De Anima and in the Sophonias' Commentary on Aristotle's text, which is included in Commentaria in Aristotelem Graeca (C.A.G.). In De Anima truth is related to the combinations of data, which are derived from sense perceptions (ai $\sigma \theta \dot{\eta} \sigma \varepsilon 1 \varsigma$ ),

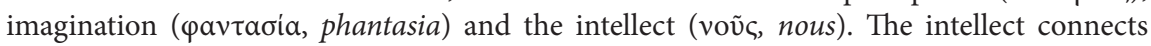
the initial data through logic and observes the variety of the combinations of reality. During that combinational process of logic, it is possible that falsehood can penetrate, so that the combinations of intellect do not comply with the existing combinations of reality. As a result, falsehood, according to Aristotle, originates from the non-proper synthesis and analysis of the meanings. On the contrary, Sophonias rests upon elements of the Platonic philosophy, claiming that the divine intellect coincides with God and truth.
\end{abstract}

Key words: Aristotle, De Anima, Sophonias, Commentaria in Aristotle Graeca

\begin{abstract}
Abstrakt: NTOTSIKA, Alexantra. Pravda podla Aristotela a Sophoniasa. Cielom tohto článku je odhalit filozofickú hru medzi pravdou a nepravdou, ako je táto prezentovaná v Aristotelovom pojednaní De Anima a v Sophoniasovom komentári k Aristotelovmu textu, ktorý sa nachádza v rámci diela Commentaria in Aristotelem Graeca (C.A.G.). Pravda je v spise De Anima chápaná vo vztahu ku kombinácii dát, ktoré sú odvodené zo zmyslového vníma-

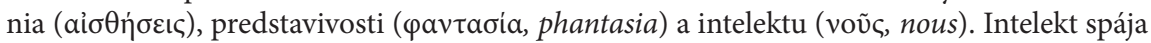
východiskové dáta prostredníctvom logiky, pričom si všíma rôznost kombinácií skutočnosti. Nepravda potom $\mathrm{v}$ dôsledku toho podla Aristotela vzniká z nesprávnej syntézy a analýzy významov. Sophonias naproti tomu vychádza z téz platónskej filozofie, pričom tvrdí, že božský intelekt sa zhoduje s Bohom a pravdou.
\end{abstract}

Klúčové slová: Aristoteles, De Anima, Sophonias, Commentaria in Aristotle Graeca

\section{THE TRUTH IN ARISTOTLE}

The philosophical game of truth or falsehood is based on the relation between senses, imagination and intellect. The sense perception (ailo $\theta \eta \sigma \iota \varsigma)$ is one of the powers through which we are capable of making judgements (Aristotle, De Anima 426b 21-24, 427a 19-21) and is true of its own proper

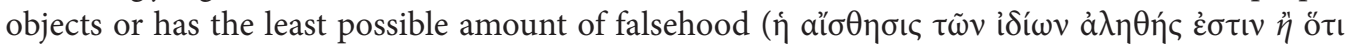

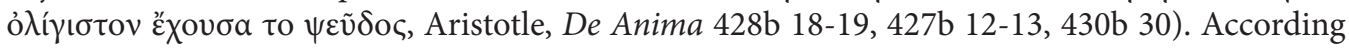
to Aristotle's understanding of sense perception, each of the five senses perceives one type of "perceptible" or "sensible" which is specific ( $(\delta\llcorner\alpha$, Aristotle, De Anima 418a 11-12). That is the kind of stimulus that is proper to the sense and to which the sense is adapted to be sensitive (colour for sight, sound for hearing, etc.) Nevertheless, with the minimum (ỏ $\lambda$ í that falsehood is potentially able to penetrate even into the specific or particular of the senses (' ${ }^{\prime} \delta \mathrm{i} \alpha$ 


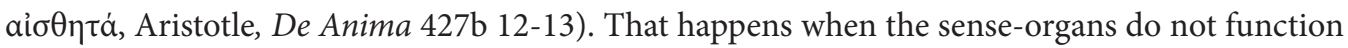
properly.

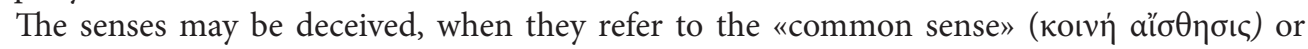
to the incidental $(\sigma v \mu \beta \varepsilon \beta \eta \kappa o ́ \tau \alpha)$. Common sensation is possessed, to varying degrees, by any and all of the senses and perceives common sensibles namely (movement/change, rest, number, figure, magnitude). The ability to discern these sensibles is common to more than one sense and is not due to a particular, dedicated sense organ or sense (Kerr no date). This term is explained by the philosopher in the following example:

When we see the son of Cleon not as the son of Cleon but as something white with which object there happens to coincide the fact of being the son of Cleon (Aristotle, De Anima 425a 24-28).

The senses, therefore, are able to initially conceive that both the colour white, that happens to be Cleon's son, and the human are becoming perceivable because of his colour. Vision initially recognizes the white colour in order to finally decide upon the substance (Cleon's son) and not on its own proper object (' $(\delta \mathrm{i} / \mathrm{v})$. The sense-objects in common, where falsehood can penetrate, are movement/change, rest, number, shape, magnitude (Alexander of Aphrodisias, De Anima 41.1-4). Qualities of this kind are proper to no one sense, but are common to all.

\subsection{Intellect}

When it comes to the question between the relation of the intellect and truth and falsehood, there is an adequate analysis on the chapter 5 of the third book in the Aristotelian treatise. In spite of the chapter consisting of just 15 lines, there are various interpretations and thousands of comments on it (Ross 1995, Anton 1957). It is also the first and only time that the popular

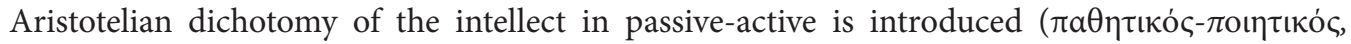
Brentano 1977, 1992, Caston 1999, Hartman 1977, Johansen 2012, Polansky 2008, Rist 1966, White 2004). To be more specific, for the passive intellect, there is a two-line reference:

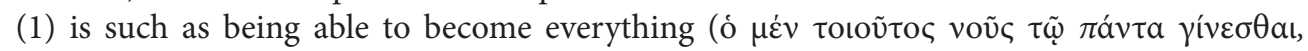
Aristotle, De Anima 430a 14),

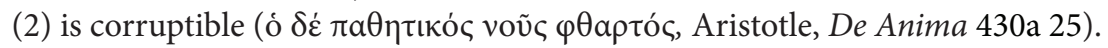

The intellect, which can be everything, is passive in the sense that it can be characterized as matter that can take all forms, it is not separated from the body, but it becomes subject to the laws of decay that govern the physical objects.

The active intellect is described as follows:

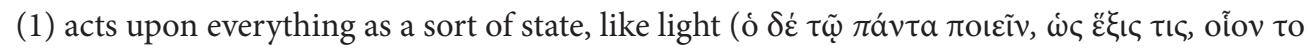
$\varphi \tilde{\omega} \varsigma$, Aristotle, De Anima 430a 14-15),

(2) is separable, uncompounded and incapable of being acted on, a thing essentially in act (Kai

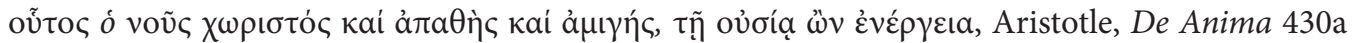
17-18),

(3) only separated is it what really is and this alone is immortal and perpetual in human

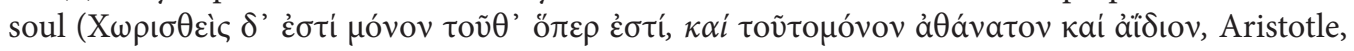
De Anima 430a 22-23).

As a result, as the light is necessary for the colours to be visible, in the same vein does the passive intellect need the energy of the active to receive the ability to understand (vociv, noein, Aristotle, De Anima 429a 13-18).

The active intellect, as an energetic element, is more valuable than the passive, same as the cause toward matter. This metaphor aims to show that the active intellect operates freely 
and constructively (During 1994) in the inferior contemporary and individual intellectual potentiality. As a consequence, the relation between these two kinds of intellect included in the Aristotelian model of matter and form.

The active intellect, after the body's decay, is separated from the passive intellect and becomes what it is ( $\tau \circ \tilde{v} \theta$ ' ö $\varepsilon \rho \rho \dot{\varepsilon} \sigma \tau i$, Aristotle, De Anima 430a 22-23). It seems that during its connection with the passive intellect, its true nature is hidden and only when it actually separated from the body, is

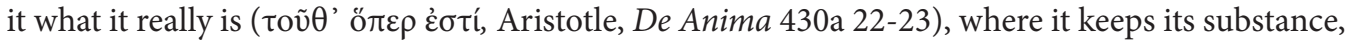
the only immortal within the human soul.

In summary, the philosophical issue about truth and falsehood is briefly presented in chapter 5 of the third book of the treatise. The philosopher answers the question while he introduces the concept of active-passive intellect. When the active and the passive intellect combine together, they eventually form two distinct conditions of the same soul potentiality. The two conditions are distinguished based on their functional and evaluating position (During 1994). There is no further clarification as to whether the active intellect is God or something divine inside humans or a cosmic natural force or something else. It appears as detached from the organs and the body in which it belongs. Nonetheless, it functions as act (entelechy, entelechia, $\dot{\varepsilon} v \tau \varepsilon \lambda \dot{\varepsilon} \chi \varepsilon \mid \alpha)$ for the time being inside the human and it is presented as an element of the human soul. In addition, the active and the passive intellect do not comprise powers that can be divided from each other, contrariwise they constitute substances that exist as such, namely as two conditions in the intellective potentiality of the human soul. The potential intellect towards the intellective forms acts as a pure and clear capability to perceive forms (Aristotle, De Anima 429b 15-16, 28-29), and for that reason it constitutes the first potentiality, which leads to the second energy.

\section{2 Imagination}

Imagination according to Aristotle is defined as a motion that comes from the senses but it transcends them (Aristotle, De Anima 429a). The role of imagination is to mediate between the sense and the intellect (Aristotle, De Anima 433a 1-30). Imagination (phantasy) constitutes one of the powers on the basis of which we are able to make judgements and to be truth or false. Meanwhile, while the senses are always true, the imagination (phantasy) is mainly false. For that reason, when the sense is accurate, we do not use the phrase "I imagine this is a human being" (Aristotle, De Anima 428a 1-11). On the contrary, this phrase is used when we are not sure for something, when we lack accuracy or clarity.

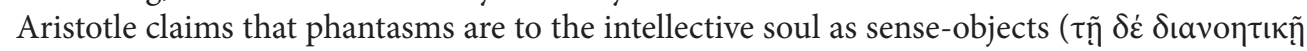

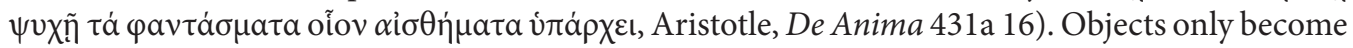
actually intelligible, when abstracted from phantasms (Aquinas 1946). It can be concluded that the moving from the senses to intellect can be achieved through the mediation of the imagination that derives from the senses. The intellect traces back in imagination, to synthesize, evaluate and decide, whether something is truth or falsehood, in other words, it goes back to the products of experiences, the objects of the world. In this light, truth and falsehood constitute a philosophical subject that takes place within the human intellect, within the human soul with material that originates from what we see, touch, hear, feel, the things or the ways we experience the world with.

Falsehood can enter in the area where combination of the sense perception, imagination and intellect occur. The intellect connects the initial data through logic and observes the variety of the combinations of reality. During that combinational process oflogic, it is possible that falsehood can penetrate, so that the combinations of intellects do not comply with the existing combinations of reality. As a result, falsehood, according to Aristotle, originates from the non-proper synthesis 
and analysis of the meanings. Human knowledge completely corresponds with reality, when synthesis or combinations of the data of reality have been properly achieved. Furthermore, the world is exactly compatible with what our senses and intellect reveal, only when there is no intellectual false or pathological disturbance.

\section{THE TRUTH IN SOPHONIAS}

Sophonias claims that sense perception is always true of its own proper objects ('i $\delta ı \alpha$ ai $\sigma \theta \eta \tau \dot{\text {, }}$ Sophonias, De Anima 112.27-28). He also claims that falsehood is due to the synthesis of the meanings (Sophonias, De Anima 122.36-123.21). Nevertheless, the most important element that is intertwined with the philosophical question of truth and it essentially differentiates from the Aristotelian view is the triple dichotomy of the intellect:

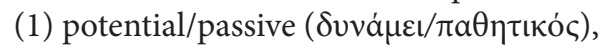

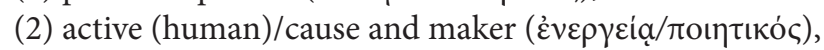

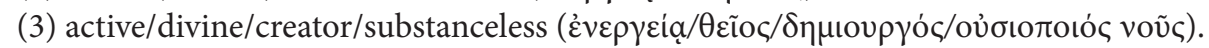

Sophonias agrees with Aristotle and claims that as in nature there is matter and causa, similarly the mind is divided in potential/passive and active, which is the cause and maker, in that it makes all (which is what art does in relation to the material). It further separates the active intellect into human and divine, and in this way he introduces a third form of intellect, the active/creator/

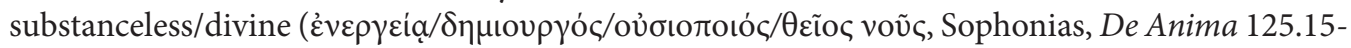
21, 125.21-23).

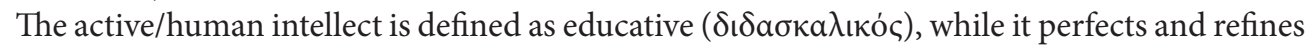
the potential (Sophonias, De Anima 115.35-116). The human intellect needs to be trained, because it doesn't possess the theory of everything, as the divine intellect does, hence it needs to make a reasoning course (Sophonias, De Anima 140.26-40) to judge and conclude (Sophonias, De Anima 132.32-39, 133.19-24). The divine intellect acts as omniscient, since it is the one that possesses knowledge (Sophonias, De Anima 133.19-24). It is the source of creativity, it is clear and timeless, an opinion that reminds the current notion of divine.

The Commentator also goes one step further and introduces the idea that the soul's decay occurs, because it is connected with the human body and that the idols are images of reality, something like a reflection of the senses-objects of the world or the reflection of truth in the world, an opinion with a Platonic shade. In this light it is possible to explain the use of terms such as "oblivio", "idols" [etc.] that refer to the Platonic theory of memory or ideas. However, the Platonic theory of ideas is redefined within a Christian spectrum. Platonic ideas lose their definition as sources of absolute truth, whereas, in their place, there is now the active/divine mind (Sophonias, De Anima 143.10-30). This assertion is reinforced by the fact that Sophonias guide the reader to follow the voice of God-Saviour (Sophonias, De Anima 151.32-152.6).

The Aristotelian treatise, however, does not comprise a theological work, contrariwise, it is included in the philosophers works on physics aiming at the investigation and definition of nature. The philosopher, as physical scientist, offers an analysis of the biological-normal functions and expressions of the soul, which he comprehends as the beginning and the reason of the existence of the living beings (Oehler 1997).

According to Aristotle, the ability to think about truth involves a process that takes place inside the human soul and through the senses, imagination, experience and intellect in various ways. On the contrary, Sophonias consequently constructs a completely different philosophical work. He rests upon elements of the platonic philosophy, claiming that the divine intellect coincides with God and truth. The divine intellect preexists as something indisputability, timeless, perpetual 
and therefore it does not derive from the variety of the combinations of reality inside the human soul in various ways.

\section{REFERENCES}

\section{Primary sources}

Alexander of Aphrodisias. 1887. Alexandri Aphrodisiensis Praeter Commentaria Scripta Minora.

De Anima Liber Cum Mantissa, edited by I. Bruns. Commentaria in Aristotelem Graeca, Supplementum Aristotelicorum, Vol. II pars I, G. Reimer, Berolini.

Aquinas, Thomas St. 1946. The Commentary of St. Thomas Aquinas on Aristotle's Treatise

On the Soul, translated by R.A. Kocourek, St. Paul, Minnesota.

Aristotle. 1956. De Anima, ed. W.D. Ross, Oxford Classical Texts, Oxford.

Aristotle. 1957. On the Soul. Parva Naturalia. On Breath. Translated by W. S. Hett. Loeb Classical Library 288. Cambridge.

Aristotle. 1968. De Anima, Books II \& III (with certain passages from book I), translated with an introduction and notes by D. Hamlyn, Clarendon Aristotle Series, Oxford.

Aristotle. 1976. De Anima, with translation, introduction and notes by R. Hicks. New York. Aristotle. 1993. Aristotle's De Anima in focus, edited by M. Durrant, London and New York.

Aristotle. 1998. De Anima, with introduction, translation and notes by V. Tatakis edited by

E. Papanoutsos, Daidalos-Zacharopoulos, Athens.

Aristotle. no date. De Anima, II-III text, translation and notes by A. Papatheodorou (in Greek). Athens.

Sophonias. 1883. In Libros Aristotelis De Anima Commentaria, edited by M. Hayduck. Commentaria in Aristotelem Graeca, Vol. XXIII, Part 1, G. Reimer, Berlin.

\section{Secondary sources}

Anton, John. 1957. Aristotle's theory of contrariety, Routledge and Kegan Paul Limited.

Brentano, Franz. 1992. Nous Poiêtikos: Survey of Earlier Interpretations. In Nussbaum, Martha Rorty, Richard (eds.). Essays on Aristotle's De Anima. Oxford, 313-341.

Brentano, Franz. 1977. The Psychology of Aristotle. In Particular His Doctrine of the Active

Intellect. With an Appendix Concerning the Activity of Aristotle's God, ed. Rolf George. Berkeley - Los Angeles - London.

Caston, Victor. 1999. Aristotle's Two Intellects: A modest proposal. In Phronesis 44/3, 199-227.

During, Ingeman. 1994. Aristotle. Athens.

Ebbesen, Sten. 1981. Commentators and Commentaries on Aristotle>s Sophistici Elenchi, Brill. Fryde, Edmunt. 2000. The Early Palaeologan Renaissance (1261- c. 1360). Leiden - Boston - Köln. Ierodiakonou, Katerina. $2014\left(2008^{1}\right)$. "Byzantine Philosophy". Stanford Encyclopedia of Philosophy. https://plato.stanford.edu/entries/byzantine-philosophy/

Johann, Kim. 1998. Intellectual virtues according to Aristotle (in Greek). Athens.

Johansen, Thomas. 2012. The powers of Aristotle's soul. Oxford.

Kerr, Scott. no date. In-Itself and Incidental Perception in De Anima. https://www.academia.edu. 
Ntotsika, Alexantra. 2014. Truth of the intellect or truth of the things?: the interpretation of the De Anima in the Ancient Commentators (Alexander of Aphrodisias, Themistius, Simplicius, Joann Philoponus, Sophonias, in Greek). Thessaloniki.

Oehler, Klaus. 1997. Subjektivität und Selbstbewußtsein in der Antike, translation in Greek Ch. Karanasios, Athens.

Polansky, Ronald. 2008. Aristotle's De anima. Cambridge.

Rist, John. 1966. Notes on Aristotle De Anima 3.5. In Classical Philology 61/1, 8-20.

Ross, William. 1991. Aristotle, translation in Greek: M. Mitsou. Athens.

White, Michael. 2004. The Problem of Aristotle's Nous Poiêtikos. In The Review of Metaphysics $57 / 4,725-740$.

SUMMARY: THE TRUTH IN ARISTOTLE AND SOPHONIAS. The purpose of the current article is to discover the philosophical game between truth and falsehood, as it is presented in the Aristotelian treatise De Anima and in the Sophonias' Commentary on Aristotle's text, which is included in Commentaria in Aristotelem Graeca (C.A.G.). In De Anima truth is related to the combinations of data, which are derived from sense perceptions (ai $\sigma \theta \dot{\eta} \sigma \varepsilon เ \varsigma$ ), imagination ( $\varphi \alpha v \tau \alpha \sigma i \alpha$, phantasia) and the intellect (voṽ $\varsigma$, nous). The intellect connects the initial data through logic and observes the variety of the combinations of reality. During this combinational process of logic, it is possible that falsehood can penetrate, so that the combinations of intellect do not comply with the existing combinations of reality. As a result, falsehood, according to Aristotle, originates from the non-proper synthesis and analysis of the meanings. On the contrary, Sophonias rests upon elements of the Platonic philosophy, claiming that the divine intellect coincides with God and truth.

More specifically according to Aristotle the philosophical game of truth or falsehood is based on the relation between senses, imagination and intellect. The sense perception (al $\sigma \theta \eta \sigma \iota)$ ) is one of the powers through which we are capable of making judgements (Aristotle, De Anima 426b 21-24, 427a 19-21) and is true of its own proper objects or has the least possible amount of falsehood (Aristotle, De Anima 428b 18-19, 427b 12-13, 430b $30)$. On the contrary, the senses may be deceived, when they refer to the "common sense" or to the incidental. While the senses are always true, imagination (phantasy) is mainly false. For that reason, when the sense is accurate, we do not use the phrase "I imagine this is a human being" (Aristotle, De Anima 428a 1-11). On the contrary, this phrase is used when we are not sure about something and therefore we lack accuracy or clarity.

Regarding the intellect and its relationship with truth, Aristotle introduces the dichotomy of passive-active nous. The intellect, which can be everything, is passive in the sense that it can be characterized as matter that can take all forms. It is not separated from the body, but it becomes subject to the laws of decay that govern the physical objects. The active intellect is separable, uncompounded, incapable of being acted on, a thing essentially in act (Aristotle, De Anima 430a 17-18). Separated is only that which really is and this alone is immortal and perpetual in human soul (Aristotle, De Anima 430a 22-23). Truth completely corresponds to reality, when the synthesis or combinations of the data of reality, which come up through the senses, imagination and experience, have been properly achieved. As a result, falsehood, according to Aristotle, originates from the non-proper synthesis and analysis of the meanings and the data of reality.

Like Aristotle before him, Sophonias claims that sense perception is always true of its own proper objects (Sophonias, De Anima 112.27-28). He also claims that falsehood is due to the synthesis of the meanings (Sophonias, De Anima 122.36-123.21). Nevertheless, the most important element that is intertwined with the philosophical question of truth, while essentially differentiating from the Aristotelian view, is the triple dichotomy of the intellect: (1) potential/passive, (2) active/human, (3) active/divine/creator/substanceless. 
Sophonias agrees with Aristotle and claims that just as there is matter and causa in nature, similarly the mind is divided in potential/passive and active, which is the cause and maker. It further separates the active intellect into human and divine. Sophonias introduces in this way a third form of intellect, the active/divine (Sophonias, De Anima 125.15-21, 125.2123), which acts as omniscient, since it is the one that possesses knowledge (Sophonias, De Anima 133.19-24). The Commentator also goes one step further and introduces the idea that the soul's decay occurs, because it is connected with the human body and because the idols are images of reality, something like a reflection of the senses-objects of the world or the reflection of truth in the world, an opinion with a Platonic shade within the Christian spectrum of thought. However, according to Aristotle, the ability to think about truth involves a process that takes place inside the human soul through the senses, imagination, experience and intellect in various ways. On the contrary, Sophonias claims that the divine intellect coincides with God and truth. Preexisting as something indisputable, timeless, and perpetual, the divine intellect is thus not derived from the variety of the combinations of reality inside the human soul.

\author{
dr. Alexantra P. Ntotsika \\ Aristotle University of Thessaloniki \\ 54124 Thessaloniki \\ Greece \\ alexantradotsika@yahoo.gr
}

